\title{
Brief Communication: An electrifying atmospheric river - understanding the thunderstorm event in Santa Barbara County during March 2019
}

\author{
Deanna Nash $^{1}$ and Leila M. V. Carvalho ${ }^{1,2}$ \\ ${ }^{1}$ Department of Geography, University of California, Santa Barbara, CA 93106, USA \\ ${ }^{2}$ Earth Research Institute, University of California, Santa Barbara, CA 93106, USA
}

Correspondence: Deanna Nash (dlnash@ucsb.edu)

Received: 15 October 2019 - Discussion started: 27 November 2019

Revised: 15 May 2020 - Accepted: 3 June 2020 - Published: 6 July 2020

\begin{abstract}
On 5 March 2019 12:00 UTC, an atmospheric river (AR) made landfall in Santa Barbara, CA, and lasted approximately $30 \mathrm{~h}$. While ARs are typical winter storms in the area, the extraordinary number of lightning strikes observed near coastal Santa Barbara made this event unique. The Earth Networks Global Lightning Network (ENGLN) detected 8811 lightning flashes around southern California (30 to $37^{\circ} \mathrm{N}$ and 130 to $115^{\circ} \mathrm{W}$ ) in $24 \mathrm{~h}$, which is roughly 2500 times the climatological flash rate in this region. The ARrelated thunderstorm resulted in approximately $23.18 \mathrm{~mm}$ accumulated precipitation in $30 \mathrm{~h}$ in Santa Barbara. This article examines synoptic and mesoscale features conducive to this electrifying AR event, characterizing its uniqueness in the context of previous March events that made landfall in the region. We show that this AR was characterized by an unusual deep moist layer extending from the low to midtroposphere in an environment with potential instability and low-elevation freezing level. Despite the negligible convective available potential energy (CAPE) during the peak of the thunderstorm near Santa Barbara, the lifting of layers with high water vapor content in the AR via warm conveyor belt and orographic forcing in a convectively unstable atmosphere resulted in the formation of hail and enhanced electrification.
\end{abstract}

\section{Introduction}

Due to recent wildfire activity in Santa Barbara County (e.g., Thomas Fire during December 2017, Whittier Fire during July 2017, and Sherpa Fire during June and July 2016) this region is at high risk for post-fire debris flow when $15 \mathrm{~min}$ of rainfall has an intensity greater than or equal to $24 \mathrm{mmh}^{-1}$ (USGS, 2019). These conditions were observed during the devastating Montecito debris flow on 9 January 2018 that resulted in 23 deaths, 246 structures destroyed, and 167 damaged structures (Oakley et al., 2018). On 1 March 2019, the National Weather Service (NWS) in Oxnard, CA, forecasted two storms to hit Santa Barbara County (1-2 March 2019 and 5-6 March 2019). On 5 March 21:00 UTC, a mandatory evacuation order was issued for the Thomas, Whittier, and Sherpa fire burn areas due to the prediction of a subsequent severe storm and flood potential that existed for lowlying areas given increased ground saturation from the storm on 2 March 2019, impacting about 3000 residents. While no significant debris flows were triggered during this event, a combination of an atmospheric river (AR) and an extreme number of lightning strikes made this storm exceptional. Figure 1a shows a photo of lightning strikes at the Santa Barbara Harbor during the storm taken by Santa Barbara County Fire Department's Mike Eliason.

The term atmospheric river (AR) describes a phenomenon that explains how baroclinic eddies transport large amounts of water vapor via relatively infrequent, long conduits of strong moisture transport across midlatitudes and into polar regions (Newell et al., 1992; Zhu and Newell, 1994). Many studies have focused on the regional impacts of ARs in the western United States and have found that ARs bring large amounts of moisture to the west coast of North America and are related to precipitation extremes and flooding, particularly in the winter season (Dettinger, 2011; Guan et al., 2010, 

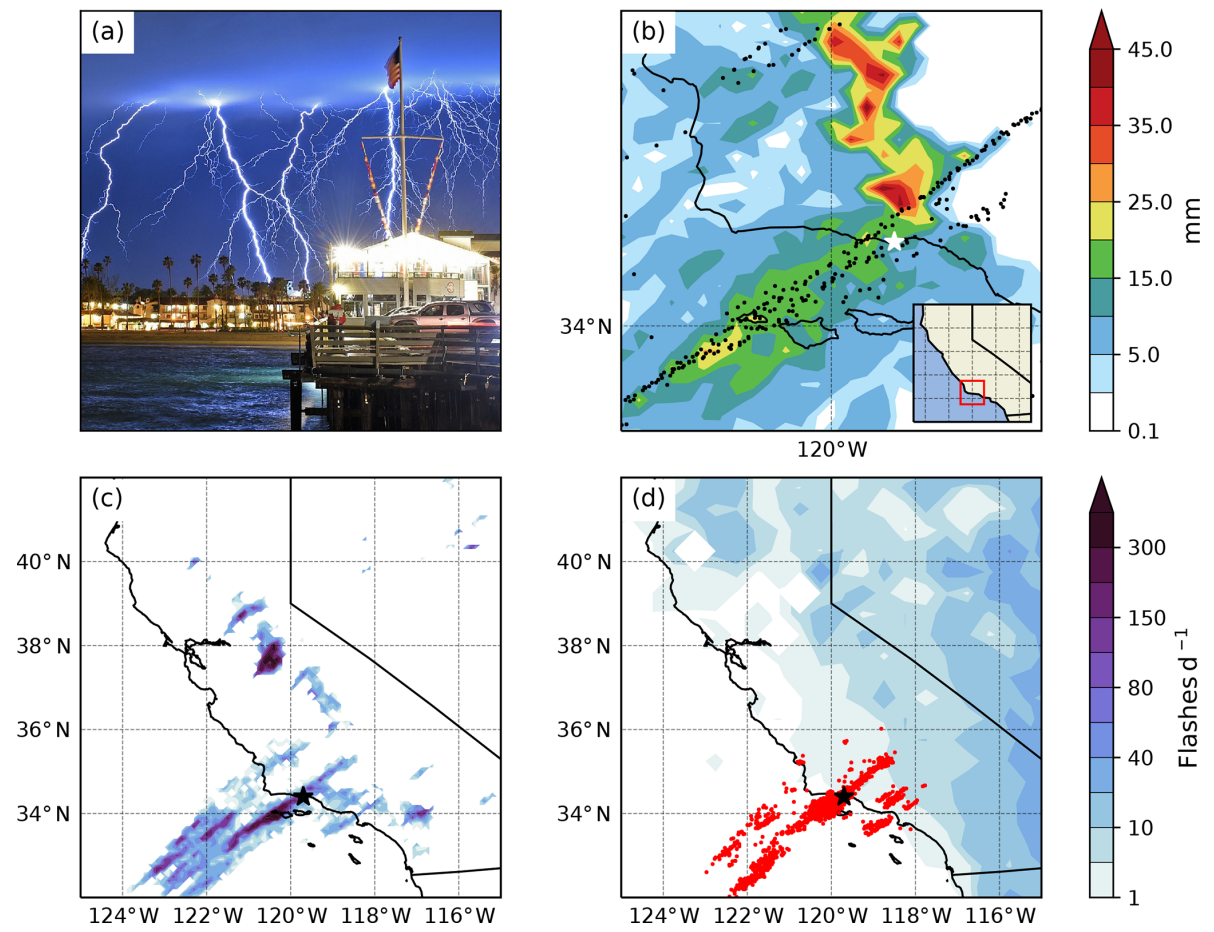

Figure 1. (a) Photo of lightning at the Santa Barbara Harbor in Santa Barbara, CA, taken by Mike Eliason from the Santa Barbara County Fire Department during the storm on 6 March 2019 04:00 UTC. (b) NOAA NEXRAD L3 precipitation accumulation (shaded; mm) and locations of NOAA NEXRAD L3 hail signatures (black points) between 5 March 2019 12:00 UTC and 6 March 2019 23:59 UTC. The location of Santa Barbara is indicated by the white star. (c) ENGLN lightning strike frequency (shaded; flashes $\mathrm{d}^{-1}$ ) on 6 March 2019. The location of Santa Barbara is indicated by the black star. (d) Climatological annual mean lightning density (shaded; flashes d ${ }^{-1}$ ) between 1995 and 2014 using TRMM LIS-OTD lightning climatology and lightning strike locations (red points) between 04:00 and 05:00 UTC on 6 March 2019 based on ENGLN. The location of Santa Barbara is indicated by the black star.

2013; Harris and Carvalho, 2018; Ralph et al., 2006). Despite occurring less frequently than ARs in northern California, the southern California ARs have a significant impact in the hydrological cycle of the region (Cannon et al., 2018; Harris and Carvalho, 2018; Oakley and Redmond, 2014; Oakley et al., 2018). Although ARs are often associated with extreme precipitation, flooding, and other hazardous events, they play a critical role in replenishing reservoirs and underground water resources, particularly in dry areas of southern California. Studies show that just a few AR events each year can contribute the majority of the precipitation and streamflow that regulates the state's water resources (Cannon et al., 2018; Dettinger, 2013; Gershunov et al., 2017; Ralph et al., 2019). Ralph et al. (2019) have developed a scale to characterize ARs based on intensity and duration, pointing out that ARs can result in a wide spectrum of conditions from beneficial to hazardous. As of now, no studies have examined the relationship between ARs and lightning.

Lightning usually occurs when the electric charges in a cloud separate and exceed the intensity that the air can sustain (Price, 2013). Charges usually build up in the mixedphase region of the clouds $\left(0\right.$ to $\left.-40{ }^{\circ} \mathrm{C}\right)$ when there are enough updrafts to lift particles above the freezing level
(Price and Rind, 1993). The correlation between cloud-top height and lightning rate is well documented and can be attributed to the deep vertical development of convective thunderstorms (Pessi and Businger, 2009; Price and Rind, 1993). Pessi and Businger (2009) documented that lightning activity can be associated with cold temperatures aloft or convection along cold fronts.

Although the thunderstorms on 5 March 2019 caused minimal damage (e.g., small lightning fires, power outages), this event was meteorologically significant because of the exceptional number of lightning strikes in such a short period. This study examines synoptic and mesoscale dynamics as well as the thermodynamic characteristics of this AR and investigates the uniqueness of this event compared to past March ARs that made landfall in Santa Barbara.

\section{Data and methods}

Climate Forecast System version 2 (CFSv2) (Saha et al., 2014) operational analysis was used in this study to evaluate the synoptic and mesoscale meteorological conditions between 10 and $50^{\circ} \mathrm{N}$ and 150 and $110^{\circ} \mathrm{W}$ between the dates 4 March 2019 18:00 UTC and 6 March 2019 18:00 UTC. 
CFSv2 data at $0.5^{\circ} \times 0.5^{\circ}$ horizontal resolution were obtained at 37 pressure levels between 1000 and $1 \mathrm{hPa}$ at a 6-hourly timescale. AR conditions are determined based on integrated water vapor transport (IVT) (see Appendix A for calculation) exceeding $250 \mathrm{~kg} \mathrm{~m}^{-1} \mathrm{~s}^{-1}$ at a fixed geographical point. The AR event in this study refers to the time that the AR conditions occurred in Santa Barbara, i.e., at the grid cell centered on $34.5^{\circ} \mathrm{N}$ and $119.5^{\circ} \mathrm{W}$. The duration of the AR event is determined by the time (in hours) that the AR conditions are consecutively met. NASA's Modern Era Retrospective Reanalysis Version 2 (MERRA-2) (Bosilovich et al., 2015; Gelaro et al., 2017) and the global atmospheric river detection catalog that identifies atmospheric rivers on a global, 6hourly basis were used to determine the anomalous characteristics of the March 2019 AR event compared to past ARs that made landfall in Santa Barbara. This AR detection algorithm was introduced in Guan and Waliser (2015) and refined in Guan et al. (2019). Here we analyzed ARs and their characteristics on a daily temporal scale at $0.5^{\circ}$ by $0.625^{\circ}$ spatial resolution between 1980 and 2018. The other calculated variables from CFSv2 are dew point (Td) and equivalent potential temperature $\left(\theta_{\mathrm{E}}\right)$, which are calculated based on Bolton (1980, Eqs. 11, 43).

Lightning flash data obtained from Earth Networks' Global Lightning Network (ENGLN) (Earth Networks, 2019) were used to quantify the location and number of lightning strikes between 4 March 2019 00:00 UTC and 7 March 2019 00:00 UTC near southern California (30 to $37^{\circ} \mathrm{N}$ and 130 to $\left.115^{\circ} \mathrm{W}\right)$. The global lightning network, which includes more than 1700 sensors, detects lightning flashes and provides various information about those flashes, including latitude, longitude, amplitude of the lightning, duration of the flash, and the number of in-cloud (IC) and cloud-to-ground (CG) lightning pulses within a given flash (Earth Networks, 2019). A lightning flash can be made up of one or more IC or CG lightning pulses, which connect regions of opposite polarity. To put the extremity of this lightning event into climatological context, an annual lightning strike climatology from Tropical Rainfall Measuring Mission Lightning Imaging Sensor and Optical Transient Detector (TRMM LIS-OTD) (Cecil, 2015) was used at a horizontal resolution of $0.5^{\circ}$ by $0.5^{\circ}$ between 1995 and 2014 from 20 to $50^{\circ} \mathrm{N}$ and 140 to $110^{\circ} \mathrm{W}$. Comparing the two lightning sources has a certain level of uncertainty, since TRMM LIS-OTD and ENGLN do not overlap temporally. However, because this event had significantly above-average lightning flash rates compared to the climatology, the possible error introduced by comparing two different data sets does not impact the results.

For precipitation, hourly precipitation data from the $\mathrm{Na}$ tional Oceanic and Atmospheric Administration's Next Generation Radar Level 3 (NOAA's NEXRAD L3) was used between the dates 4 March 2019 18:00 UTC and 6 March 2019 23:59 UTC at roughly $1 \mathrm{~km}$ resolution (NOAA National Weather Service, NWS). To identify the approximate loca- tion, time, and diameter of hail, NOAA's NEXRAD L3 hail signature product was used. To identify cloud convection and cloud-top height via cloud-top temperature, the Cloud and Moisture Imagery (CMI) product from GOES-R (GOES-17) Advanced Baseline Imager Level 2 was obtained for 6 March between 03:00 and 05:00 UTC at $5 \mathrm{~min}$ temporal intervals and $10 \mathrm{~km}$ by $10 \mathrm{~km}$ spatial resolution (GOES-R Algorithm Working Group and GOES-R Series Program, 2017).

\section{Results and discussion}

\subsection{March 2019 event}

An AR made landfall near Santa Barbara $\left(34.5^{\circ} \mathrm{N}\right.$, $119.5^{\circ} \mathrm{W}$ ) between 5 March 12:00 UTC and 6 March 18:00 UTC, resulting in total accumulated precipitation of approximately $23 \mathrm{~mm}$ around Santa Barbara according to NOAA NEXRAD L3 $1 \mathrm{~h}$ precipitation. While this was not enough precipitation to initiate debris flow, instances of hail were identified by the NOAA NEXRAD L3 hail signature product (see Fig. 1b). The presence of hail indicates strong updrafts and a low freezing level, which are conditions that also favor the development of lightning in a storm (Pruppacher and Klett, 1997). During this AR event, ENGLN detected 46222 flashes of lightning with 85032 combined IC and $\mathrm{CG}$ pulses around southern California (30 to $37^{\circ} \mathrm{N}$ and 130 to $115^{\circ} \mathrm{W}$ ) (Earth Networks, 2019). Among these, 8811 flashes of lightning with 35603 combined IC and CG pulses occurred in the $24 \mathrm{~h}$ period following 6 March 00:00 UTC (Fig. 1c). TRMM LIS-OTD records an area annual average of 3.34 flashes per day in the region surrounding southern California ( 30 to $37^{\circ} \mathrm{N}$ and 130 to $115^{\circ} \mathrm{W}$ ), making the 8811 lightning flashes in under $24 \mathrm{~h}$ very extreme. In fact, even if this was the only lightning activity for 2019, it would represent over 2500 times the climatological rate (Fig. 1d) (Cecil, 2015). Based on the AR database of Guan et al. (2019), on average 10 AR days are observed between December and March each year in Santa Barbara, with a total of $742 \mathrm{~d}$ associated with ARs that made landfall in the grid cells closest to Santa Barbara between 1980 and 2019. When compared to the TRMM LIS-OTD low-resolution time series, between 1995 and 2014 there were approximately 350 landfalling AR events that coincided with lightning flashes, with the majority of events resulting in fewer than 60 flashes per day (Cecil, 2015).

\subsection{Extratropical cyclone and AR conditions}

Following an extratropical cyclone that made landfall at 1 March 12:00 UTC, a deep mid-level $(500 \mathrm{hPa})$ trough developed into a closed low system, forming a pool of cold air centered at approximately $32^{\circ} \mathrm{N}$ and $140^{\circ} \mathrm{W}$ by 4 March 18:00 UTC (Fig. 2a). The surface low pressure was located directly below the $500 \mathrm{hPa}$ closed low on 4 March 18:00 UTC (Fig. 2a). This mid-level closed low moved east- 
ward and northward, until 6 March 12:00 UTC when it was no longer closed (Fig. 2h). According to Oakley and Redmond (2014), $41 \%-50 \%$ of precipitation in Santa Barbara between October and March is associated with closed lows. The surface low pressure deepened from $1005 \mathrm{hPa}$ to approximately $996.36 \mathrm{hPa}$ by the peak event time at 6 March 2019 06:00 UTC; at this point it was centered around $38^{\circ} \mathrm{N}$ and $126^{\circ} \mathrm{W}$, west of northern California (Fig. $2 \mathrm{~g}$ ). At the peak time of the event, 6 March 06:00 UTC, the jet streak exit region was located at $35^{\circ} \mathrm{N}$ and $122^{\circ} \mathrm{W}$, directly northwest of Santa Barbara (Fig. S1g in the Supplement). Pessi and Businger (2009) showed that most of the storms that have lightning activity over the North Pacific Ocean are associated with similar synoptic conditions as those observed during the storm in March 2019.

These synoptic conditions provided the dynamical mechanisms necessary for subtropical moisture to be transported via an AR, shown as the area of IVT greater than $250 \mathrm{~kg} \mathrm{~m}^{-1} \mathrm{~s}^{-1}$ (Fig. 2). This AR made landfall at approximately 5 March 12:00 UTC on the west coast near Santa Barbara and lasted approximately $30 \mathrm{~h}$ (Fig. 2d-i). The peak IVT value for this event within the AR was $1034 \mathrm{~kg} \mathrm{~m}^{-1} \mathrm{~s}^{-1}$ at 5 March 12:00 UTC (Fig. 2d). In the grid cell closest to Santa Barbara $\left(34.5^{\circ} \mathrm{N}\right.$ and $\left.119.5^{\circ} \mathrm{W}\right)$ the AR had a peak IVT value of $446 \mathrm{~kg} \mathrm{~m}^{-1} \mathrm{~s}^{-1}$ on 6 March 06:00 UTC (Fig. S2a in the Supplement). Based on the duration ( $30 \mathrm{~h}$ ) and maximum instantaneous IVT intensity of the AR $\left(446 \mathrm{~kg} \mathrm{~m}^{-1} \mathrm{~s}^{-1}\right)$, this event is categorized at AR-CAT 1 according to Ralph et al. (2019), indicating that this AR was most likely beneficial to the Santa Barbara area. This particular AR had IVT direction and magnitude characteristics similar to past ARs that made landfall in the Santa Barbara area (Fig. S2b and c in the Supplement).

Equivalent potential temperature at $850 \mathrm{hPa}\left(\theta_{\mathrm{E}}\right)$ (Fig. S3 in the Supplement) identifies the formation of the warm conveyor belt (WCB) or the ascending air within the warm sector of the extratropical cyclone and the overlap of the AR between 5 March 12:00 UTC and 6 March 12:00 UTC (Browning, 1986; Dettinger et al., 2015). On 6 March at 06:00 UTC (Fig. S3g in the Supplement), the cold front lies along the densely packed isotherms between the coast of California and $32^{\circ} \mathrm{N}$ and $124^{\circ} \mathrm{W}$, and the warm front is located parallel to the coast of California. This placed the region of warm air advection and the WCB in the southern region of the domain between the two fronts where $\theta_{\mathrm{E}}$ is around $320 \mathrm{~K}$. Water vapor in the $A R$, which can be sourced from intense vapor transport out of the tropics as well midlatitude convergence of water vapor along the path of the AR, was transported via winds into the WCB (Fig. S3 in the Supplement) (Dettinger et al., 2015). The uplift of the moisture from the AR most likely occurred due to orographic uplift from interaction with complex topography as well as dynamic uplift from the WCB (Fig. S3 in the Supplement). It has been suggested that WCBs and ARs can form on their own without direct connection to each other (Dettinger et al., 2015; Dacre et al., 2019).
In this case, we observed an AR interacting with a WCB, along with updrafts and hail formation. The synoptic conditions of this event show that the cyclogenesis combined with the dynamical lift of the AR in a convectively unstable environment provided enough updraft to potentially aid in the electrification of the clouds via hail formation.

\subsection{Thermodynamic conditions}

Wind in the skew $(\mathrm{t})-\log (\mathrm{p})$ diagram at $34.5^{\circ} \mathrm{N}, 119.5^{\circ} \mathrm{W}$ (Fig. 3a) for the time closest to the peak of the event (6 March 06:00 UTC) indicates strong warm air advection below $800 \mathrm{hPa}$. This strong veering profile near the surface with increasing wind speeds with height intensifies the mesocyclone and maintains the storm. Most thunderstorms are associated with high values of convective available potential energy (CAPE), which measures the amount of energy available for convection. While this storm had values of surfacebased CAPE up to $1000 \mathrm{~J} \mathrm{~kg}^{-1}$ as it made its way across the Pacific Ocean toward the west coast of California, there was little to no CAPE in Santa Barbara $\left(10 \mathrm{~J} \mathrm{~kg}^{-1}\right)$ where lightning occurred on 6 March at 06:00 UTC (Figs. 3a and S4 in the Supplement). However, like the extreme precipitation events in Cannon et al. (2018), additional dynamical forcing can develop convection even when CAPE is low. Although CAPE was low near Santa Barbara, the proximity of temperature and dew point profiles in the lower troposphere places the lifting condensation level (LCL) very close to the surface (Fig. 3a).

Between 800 and $625 \mathrm{hPa}$, parcels are saturated, indicating the high moisture content of the AR (Fig. 3a and c). The equivalent potential temperature profile (Fig. 3b) shows decreasing $\theta_{\mathrm{E}}$ with increasing height, indicating convective instability at the surface as well as in the middle levels between 800 and $600 \mathrm{hPa}$. A close inspection of the $\theta_{\mathrm{E}}$ profile at the location of the highest lightning flash density (Fig. S4 in the Supplement) indicates convective instability at nearly every $6 \mathrm{~h}$ time step for the duration of the storm. The horizontal water vapor flux $\left(\mathrm{m} \mathrm{s}^{-1}\right)$ calculated at each pressure level on 6 March 06:00 UTC at $34.5^{\circ} \mathrm{N}, 119.5^{\circ} \mathrm{W}$ (Fig. 3c) indicates that the water vapor flux peaked at $0.17 \mathrm{~m} \mathrm{~s}^{-1}$ between 800 and $700 \mathrm{hPa}$. Similar results were found when using MERRA-2, although with a slightly lower water vapor flux that occurred around $650 \mathrm{hPa}$ (Fig. 3c). Compared to the climatological vertical profile of water vapor flux from the past March AR events in Santa Barbara, the AR on 6 March 2019 was extremely moist with maximum moisture peaking at a higher-than-average pressure level (Fig. 3c). The height (kilometers above mean sea level) of the $0{ }^{\circ} \mathrm{C}$ isotherm at $34.5^{\circ} \mathrm{N}, 119.5^{\circ} \mathrm{W}$ (Fig. 3d) is around $2.5 \mathrm{~km}$ above mean sea level during the peak of the storm, which is below the average height of the $0^{\circ} \mathrm{C}$ isotherm during past AR events in Santa Barbara (Fig. S2d in the Supplement). The lifting of moist layers in these thermodynamic conditions either orographically or by the WCB resulted in conditionally unstable 

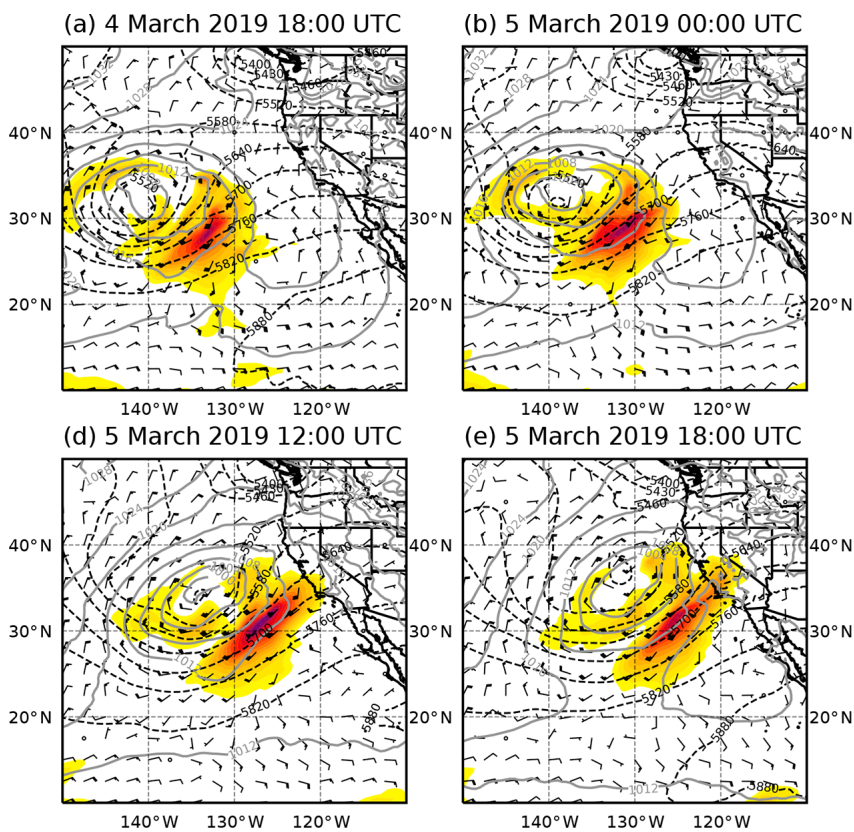

(e) 5 March 2019 18:00 UTC
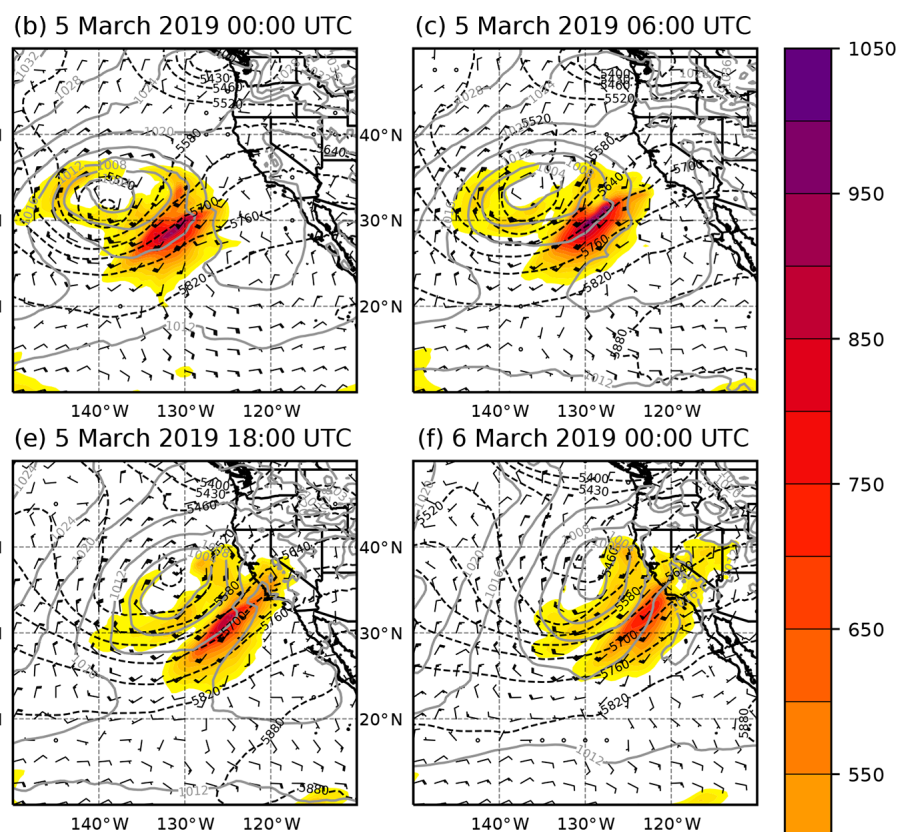

(f) 6 March 2019 00:00 UTC

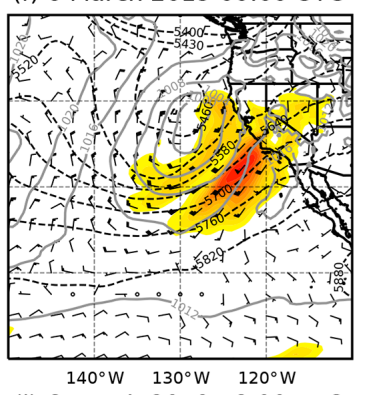

$-750$

(g) 6 March 2019 06:00 UTC

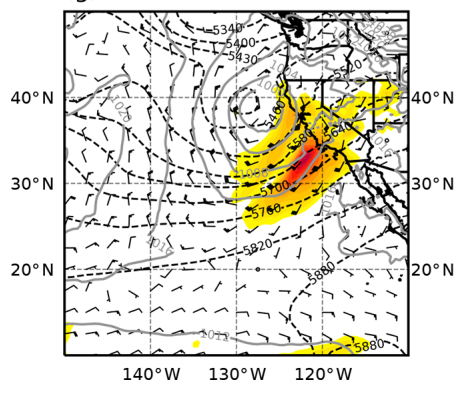

(h) 6 March 2019 12:00 UTC
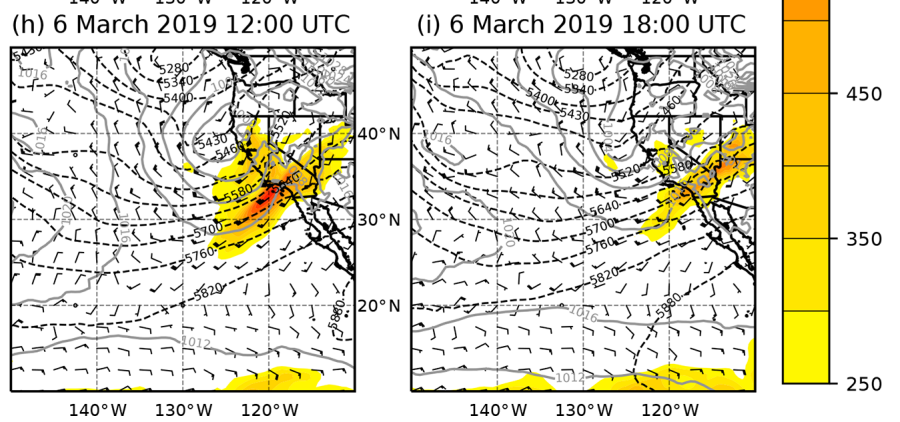

Figure 2. CFSv2 data showing IVT (shaded; $\mathrm{kg} \mathrm{m}^{-1} \mathrm{~s}^{-1}$ ), $850 \mathrm{hPa}$ wind (barbs; knots), mean sea level pressure (grey contours; hPa), and $500 \mathrm{hPa}$ geopotential height (black dashed contours; m) at 6-hourly time steps between 4 March 2019 18:00 UTC and 6 March 2019 18:00 UTC. The time step closest to the peak of the event is shown in panel (g) on 6 March 2019 06:00 UTC in the bottom left corner.

air and strong updrafts below freezing level (Fig. 3c and d). GOES-17 cloud and moisture imagery brightness temperature (Fig. S5 in the Supplement) indicates vigorous convection via cold cloud temperatures that decrease to approximately $-71^{\circ} \mathrm{C}$ near Santa Barbara at the time closest to the peak of the event. These cold top temperatures indicate a very strong updraft, which would result in hail formation when water droplets in the region of the updraft are carried above the freezing level (Wallace and Hobbs, 2006; Pruppacher and Klett, 1997). The lifting of the moist layers as well as the convective updrafts contributed to the formation of hail with an average size of $13.5 \mathrm{~mm}$, which is co-located with cold cloud-top temperatures (Fig. S5 in the Supplement), indicating the importance of deep convective updrafts for the development of the thunderstorms.

\subsection{Lightning conditions}

Convective updrafts in the lower troposphere are considered important for the buildup of regions with positive and nega- tive net charges in the mixed-phase region of the cloud ( 0 to $-40^{\circ} \mathrm{C}$ ), playing a role in the onset of lightning and thunder (Doswell, 2001; Pessi and Businger, 2009; Price and Rind, 1993; Price, 2013). Enhanced updrafts increase electrification and lightning rates because they transport droplets to below-freezing levels, increasing ice mass (Pessi and Businger, 2009). Downdrafts into the mixed-phase region of the cloud may aid in pushing hailstones downward and are important mechanisms for electrification of the storm (Price and Rind, 1993; Price, 2013). When the updrafted droplets and downdrafted hailstones collide, they can release latent heat and potentially form graupel, a softer form of hail that is warmer than its environment (Doswell, 2001; Price and Rind, 1993). Particles in the mixed-phase region of the cloud can collide with graupel and acquire positive charges when ascending (negative when descending). Over time, this process changes the storm cloud microphysics and electrical charges, resulting in a negatively charged base and a positively charged top (Doswell, 2001; Price, 2013). 


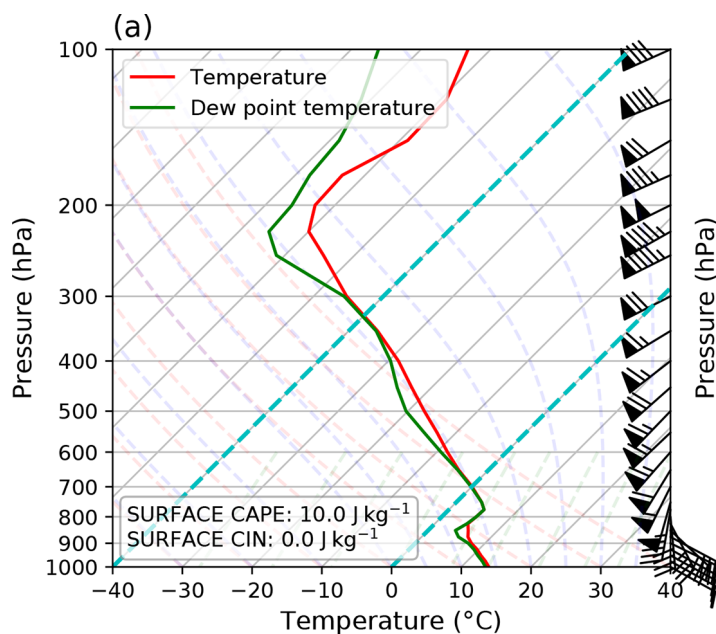

(c)

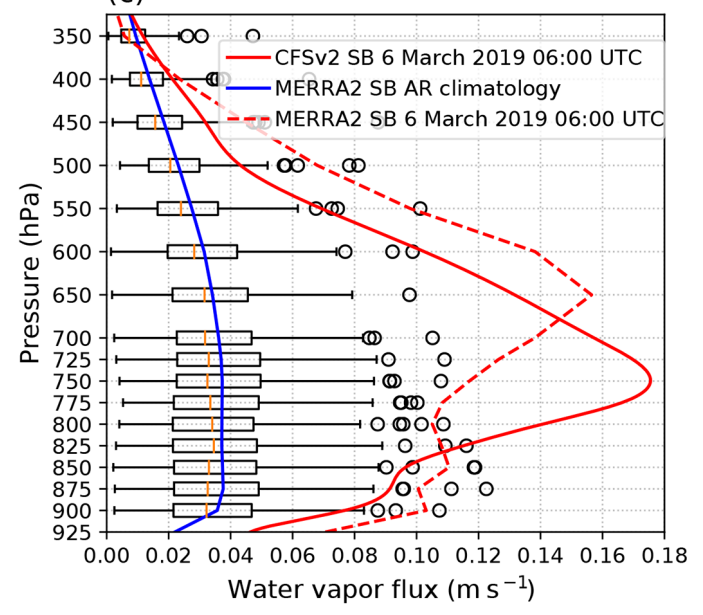

(b)

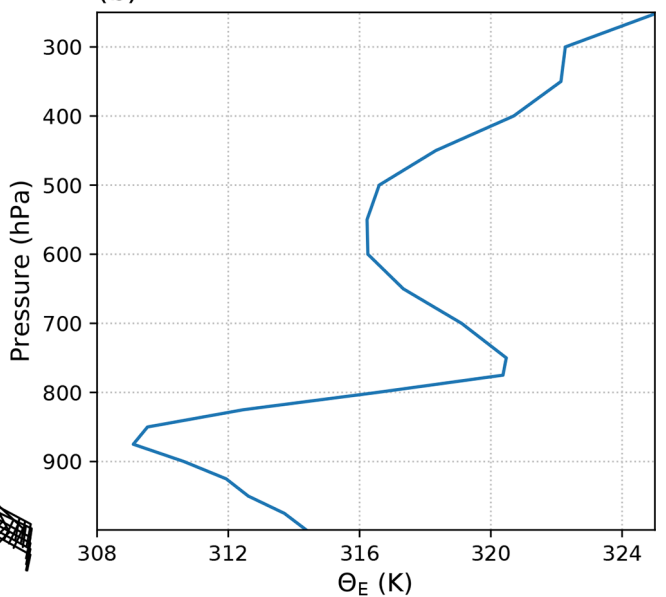

(d)

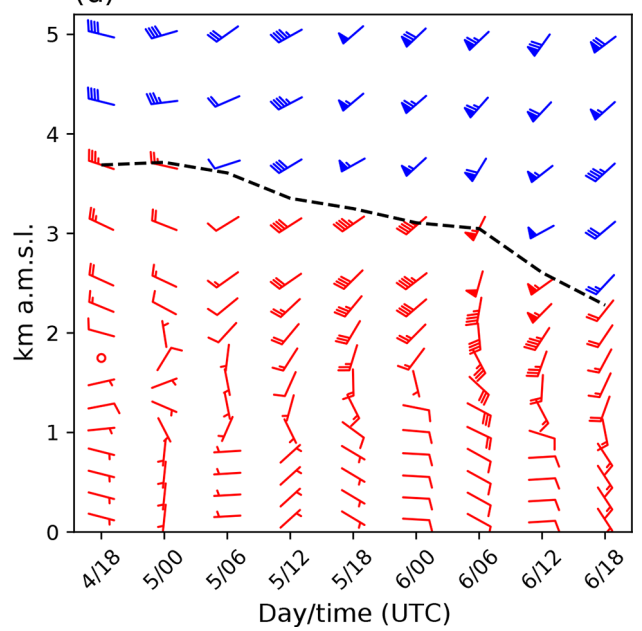

Figure 3. (a) Skew (t) $-\log (\mathrm{p})$ vertical profile of CFSv2 temperature (red line) and dew point (green line) at $34.5^{\circ} \mathrm{N}$ and $119.5^{\circ} \mathrm{W}$ on 6 March 2019 06:00 UTC. CFSv2 winds (knots; barbs) are indicated on the right side of the figure for each vertical level. Surface values of CAPE and convective inhibition (CIN) are shown in the bottom left corner. (b) CFSv2 equivalent potential temperature $\theta_{\mathrm{E}}$ (blue line; $\mathrm{K})$ at $34.5^{\circ} \mathrm{N}$ and $119.5^{\circ} \mathrm{W}$ on 6 March 2019 06:00 UTC. (c) Climatological vertical profile of horizontal water vapor flux (m s ${ }^{-1}$ ) based on MERRA-2 at $34.5^{\circ} \mathrm{N}, 119.375^{\circ} \mathrm{W}$ for all days when AR conditions are met during the month of March between 1980 and 2015 (i.e., IVT $>=250 \mathrm{~kg} \mathrm{~m}^{-1} \mathrm{~s}^{-1}$ ) at this location (blue line and box-and-whisker plots show the distribution of the 170 events), and vertical profile of horizontal water vapor flux $\left(\mathrm{m} \mathrm{s}^{-1}\right.$ ) based on CFSv2 (red solid line) and MERRA-2 (red dashed line) at the same location on 6 March 2019 06:00 UTC. (d) CFSv2 winds (knots, barbs) at vertical levels (kilometers above mean sea level) at $34.5^{\circ} \mathrm{N}$ and $119.5^{\circ} \mathrm{W}$ at $6 \mathrm{~h}$ intervals from 4 March 2019 18:00 UTC to 6 March 2019 18:00 UTC. The temperature $\left({ }^{\circ} \mathrm{C}\right)$ is indicated by the color of the barb. Red barbs mean the temperature was greater than $0^{\circ} \mathrm{C}$, and blue barbs mean the temperature was less than $0^{\circ} \mathrm{C}$. The height of the $0{ }^{\circ} \mathrm{C}$ isotherm is indicated by the black dashed line.

In the March 2019 storm, updrafts in the deep convective clouds, identified by overshooting cloud tops (Fig. S5 in the Supplement), could have transported smaller droplets to above the freezing level (below $700 \mathrm{hPa}$ ), potentially allowing for the formation of hail with a positive charge (Figs. 3a, $\mathrm{d}, 1 \mathrm{~b}$, and S5 in the Supplement). At the time closest to the peak of the event in Santa Barbara, dry air was entrained between 600 and $400 \mathrm{hPa}$ as well as in the upper levels between 300 and $200 \mathrm{hPa}$ (Fig. 3a), which could have enhanced downdrafts contributing in the formation of electrified hailstones.
According to Price and Rind (1993), the proportion of in-cloud (IC) to cloud-to-ground (CG) lightning pulses in thunderstorms is well correlated with the thickness of the cloud region between $0{ }^{\circ} \mathrm{C}$ and the top of the cloud. Therefore, as the thickness of the thunderstorm cloud increases, the ratio of IC to CG also increases. Here we use cloud-top height from GOES-R (GOES-17) Advanced Baseline Imager Level 2 (Fig. S7 in the Supplement) and the height of the $0^{\circ} \mathrm{C}$ isotherm (Fig. S8 in the Supplement) as a proxy for cloud thickness. Figure S6a shows the number of IC pulses and CG pulses every 15 min between 4 March 00:00 UTC 
and 7 March 00:00 UTC in the region of the extratropical cyclone. Between 4 March 00:00 and 12:00 UTC, there are between 2000 and $3000 \mathrm{CG}$ pulses and about 1000 to $2000 \mathrm{IC}$ pulses centered around $26^{\circ} \mathrm{N}$ and $136^{\circ} \mathrm{W}$. The second peak in lightning occurs at approximately 5 March 12:00 UTC with almost $4000 \mathrm{CG}$ pulses and 3000 IC pulses centered around $30^{\circ} \mathrm{N}$ and $128^{\circ} \mathrm{W}$ (Fig. S6a in the Supplement). The last peak of lightning frequency occurred between 6 March 00:00 UTC and 06:00 UTC with approximately 3000 IC pulses and fewer than 1000 CG pulses centered at $34^{\circ} \mathrm{N}$ and $120^{\circ} \mathrm{W}$ (Fig. S6a in the Supplement). The cloud-top height near the lightning throughout the event is between 9000 and $10000 \mathrm{~m}$ (Fig. S7 in the Supplement). However, the $0^{\circ} \mathrm{C}$ isotherm near the lightning drops closer to the ground as time passes, indicating that the cloud thickness increases as the event progresses (Fig. S8 in the Supplement). The height of the IC pulses is below $5000 \mathrm{~m}$ before 5 March 12:00 UTC and between 7500 and $10000 \mathrm{~m}$ after 5 March 18:00 UTC (Fig. S6b in the Supplement). The increased IC pulse height (Fig. S6b in the Supplement) could be explained by the increased cloud thickness between the height of the $0^{\circ} \mathrm{C}$ isotherm and the cloud top in the later half of the storm (after 5 March 18:00 UTC), similar to the findings of Price and Rind (1993).

\section{Conclusions}

On the coast of Santa Barbara, CA, an extratropical cyclone and an AR made landfall on 5 March 2019 12:00 UTC. The AR intensified until its peak on 6 March 06:00 UTC, resulting in precipitation via uplift from the WCB and orographic forcing. This event was associated with cold top clouds and vigorous convection that reached its peak at 6 March 2019 04:00 UTC. While the accumulated rainfall seen during this storm (about $23 \mathrm{~mm}$ ) is not uncommon in winter storms associated with ARs making landfall in southern California, this system exhibited extraordinary lightning activity for the region. In $30 \mathrm{~h}$ between 5 March 12:00 UTC and 6 March 18:00 UTC, ENGLN detected 46222 flashes of lightning with 85032 combined IC and CG pulses around southern California ( 30 to $37^{\circ} \mathrm{N}$ and 130 to $115^{\circ} \mathrm{W}$ ). Of those, 1486 lightning pulses occurred over Santa Barbara County in the $24 \mathrm{~h}$ following 6 March 00:00 UTC, 533 of which were cloud-to-ground type.
The lightning activity can be considered highly unusual in a region that observes, on average, fewer than 23 lightning flashes in the entire month of March. Although the system evolved as a typical winter storm associated with a cutoff low, it was exceptional due to the high water vapor content provided by the AR, particularly at mid-levels of the atmosphere. The AR developed in a troposphere cooler than average for an $\mathrm{AR}$, as indicated by the low elevation of the $0{ }^{\circ} \mathrm{C}$ isotherm (about $2.5 \mathrm{~km}$ above mean sea level). The AR provided higher-than-average horizontal water vapor flux between 800 and $600 \mathrm{hPa}$ compared to other March landfalling ARs in Santa Barbara. Unlike most thunderstorms in the tropics, this event was not characterized by significant CAPE when the storm approached the coast. However, thermodynamic profiles indicated layers with potential instability near the surface and in the mid-troposphere throughout the life cycle of the thunderstorms. The uplift of saturated parcels in a convectively unstable atmosphere from the WCB and further by the orographic forcing resulted in enhanced updrafts. These updrafts transported droplets in a cold environment and high moisture availability from the AR, providing the ingredients to form hail. Downdrafts enhanced by entrainment between 600 and $400 \mathrm{hPa}$ may have contributed to the downward transport of hail, helping to transform the charge distribution in the clouds, enhancing lightning activity. Understanding the dynamics of this storm provides the theoretical basis for future systematic investigation of the relationship between ARs and unusual lightning scenarios in other regions. It is also critical to understand these processes in populated areas such as Santa Barbara, where lightning can significantly increase hazards during rainfall events. 


\section{Appendix A: Calculation of IVT}

Integrated water vapor transport (IVT), a variable widely used for the detection and identification of ARs (e.g., Guan and Waliser, 2015; Ralph et al., 2019; Dettinger et al., 2015), is derived from specific humidity and wind fields at 17 pressure levels between 1000 and $300 \mathrm{hPa}$ inclusive from the CFSv2 operational analysis. IVT is calculated in the zonal $(x)$ and meridional $(y)$ directions using the following equations:

$\operatorname{IVT}_{x}=-\frac{1}{g} \int_{1000}^{300} u q \mathrm{~d} p$

$\operatorname{IVT}_{y}=-\frac{1}{g} \int_{1000}^{300} v q \mathrm{~d} p$

where $g$ is the gravitational acceleration, $u$ is zonal wind, $v$ is meridional wind, $q$ is specific humidity, $p$ is pressure, and the column integration is between the pressure levels 1000 and $300 \mathrm{hPa}$ inclusive. 
Code and data availability. The code for this analysis can be found at https://doi.org/10.5281/zenodo.3885717 (Nash, 2020). May et al. (2008-2017) was used for the development of some of the figures. CFSv2 data (Saha et al., 2014), TRMM LIS-OTD lightning climatology (Cecil, 2015), GOES-R data (GOES-R Algorithm Working Group and GOES-R Series Program, 2017), MERRA-2 data (Global Modeling and Assimilation Office , GMAO; Gelaro et al., 2017), and NOAA NEXRAD L3 data (NOAA National Weather Service, NWS) are all freely available online. The global AR database based on MERRA-2 and the detection algorithm from Guan and Waliser (2015) used to identify AR events between 1980 and 2019 are freely available at https://ucla.box.com/ARcatalog (Guan, 2019). The lightning data used for this study were freely provided by Earth Networks (Earth Networks, 2019).

Video supplement. Nash (2019) shows the time lapse of GOES17 ABI L2+ Cloud and Moisture Imagery Brightness Temperature from 4 to 6 March 2019 during the storm that occurred on the west coast of California in early March 2019. The video supplement can be found at https://doi.org/10.5446/43737.

Supplement. The supplement related to this article is available online at: https://doi.org/10.5194/nhess-20-1931-2020-supplement.

Author contributions. LMVC conceptualized this article and participated in the interpretation of the data. DN participated in data collection, analysis, interpretation, and drafting of the article. All authors participated in the revision and final version of the article.

Competing interests. The authors declare that they have no conflict of interest.

Acknowledgements. The authors would like to thank Duane Waliser and Bin Guan at NASA's Jet Propulsion Laboratory in Pasadena, CA, Tessa Montini at the University of California, Santa Barbara, and Forest Cannon at Scripps Institution of Oceanography for insights into this event. The authors would also like to thank Mike Eliason of the Santa Barbara County Fire Department for providing the lightning picture in Fig. 1a.

Financial support. This research has been supported by the NASA Earth and Space Science Fellowship Program (grant no. 80NSSC18K1412).

Review statement. This paper was edited by Joaquim G. Pinto and reviewed by three anonymous referees.

\section{References}

Bolton, D.: The Computation of Equivalent Potential Temperature, Mon. Weather Rev. 108, 1046-1053, $\quad$ https://doi.org/10.1175/1520 0493(1980)108<1046:tcoept>2.0.co;2, 1980.

Bosilovich, M., Lucchesi, R., and Suarez, M.: MERRA-2: File specification, Global Modeling and Assimilation Office, NASA Goddard Space Flight Center, Greenbelt, MD, USA, 2015.

Browning, K. A.: Conceptual models of precipitation systems, Weather Forecast., 1, 23-41, https://doi.org/10.1175/15200434(1986)001<0023:CMOPS>2.0.CO;2, 1986.

Cannon, F., Hecht, C. W., Cordeira, J. M., and Ralph, F. M.: Synoptic and Mesoscale Forcing of Southern California Extreme Precipitation, J. Geophys. Res.-Atmos., 123, 13-714, https://doi.org/10.1029/2018JD029045, 2018.

Cecil, D. J.: LIS/OTD Gridded Lightning Climatology Data Collection Version 2.3.2015, NASA EOSDIS Global Hydrology Resource Center Distributed Active Archive Center Huntsville, AL, https://doi.org/10.5067/LIS/LIS-OTD/DATA311, 2015.

Dacre, H. F., Martinez-Alvarado, O., and Mbengue, C. O.: Linking atmospheric rivers and warm conveyor belt airflows, J. Hydrometeorol., 20, 1183-1196, https://doi.org/10.1175/JHM-D18-0175.1, 2019.

Dettinger, M.: Climate change, atmospheric rivers, and floods in California - a multimodel analysis of storm frequency and magnitude changes, JAWRA J. Am. Water Resour. Assoc., 47, 514 523, 2011.

Dettinger, M., Ralph, F. M., and Lavers, D. A.: Setting the stage for a global science of atmospheric rivers, EOS Earth Space Sci. News, 96, https://doi.org/10.1029/2015EO038675, 2015.

Dettinger, M. D.: Atmospheric rivers as drought busters on the US West Coast, J. Hydrometeorol., 14, 1721-1732, 2013.

Doswell, C. A.: Severe convective storms - An overview, in: Severe convective storms, Springer, 1-26, https://doi.org/10.1007/9781-935704-06-5_1, 2001.

Earth Networks: Earth Networks Global Lightning Network, available at: https://www.earthnetworks.com/product/ weather-sensors/lightning/, last access: 18 July 2019.

Gelaro, R., McCarty, W., Suárez, M., Todling, R., Molod, A., Takacs, L., Randles, C., Darmenov, A., Bosilovich, M., Reichle, R. H., Wargan, K., Coy, L., Cullather, R., Draper, C., Akella, S., Buchard, V., Conaty, A., da Silva, A., Gu, W., Kim, G.-K., Koster, R., Lucchesi, R., Merkova, D., Nielsen, J., Partyka, G., Pawson, S., Putman, W., Rienecker, M., Schubert, S., Sienkiewicz, M., and Zhao, B.: The Modern-Era Retrospective Analysis for Research and Applications, Version 2 (MERRA-2), J. Climate, 30, 5419-5454, 2017.

Gershunov, A., Shulgina, T., Ralph, F. M., Lavers, D. A., and Rutz, J. J.: Assessing the climate-scale variability of atmospheric rivers affecting western North America, Geophys. Res. Lett., 44, 7900 7908, https://doi.org/10.1002/2017GL074175, 2017.

Global Modeling and Assimilation Office (GMAO): MERRA-2 inst6_3d_ana_Np: 3d, 6-Hourly, Instantaneous, Pressure-Level, Analysis, Analyzed Meteorological Fields V5.12.4, Greenbelt, MD, USA, Goddard Earth Sciences Data and Information Services Center (GES DISC), https://doi.org/10.5067/A7S6XP56VZWS, 2015.

GOES-R Algorithm Working Group and GOES-R Series Program: NOAA GOES-R Series Advanced Baseline Imager 
(ABI) Level 2 Cloud and Moisture Imagery Products (CMIP) Band 13, NOAA National Centers for Environmental Information, https://doi.org/10.7289/V5736P36, 2017.

Guan, B.: AR Catalog: AR Reanalysis Databases, available at: https://ucla.app.box.com/v/ARcatalog, last access: 24 September 2019.

Guan, B. and Waliser, D.: Detection of atmospheric rivers: Evaluation and application of an algorithm for global studies, J. Geophys. Res.-Atmos., 120, 12514-12535, https://doi.org/10.1002/2015JD024257, 2015.

Guan, B., Molotch, N., Waliser, D., Fetzer, E., and Neiman, P.: Extreme snowfall events linked to atmospheric rivers and surface air temperature via satellite measurements, Geophys. Res. Lett., 37, L20401, https://doi.org/10.1029/2010GL044696, 2010.

Guan, B., Molotch, N., Waliser, D., Fetzer, E., and Neiman, P.: The 2010/2011 snow season in California's Sierra Nevada: Role of atmospheric rivers and modes of large-scale variability, Water Resour. Res., 49, 6731-6743, 2013.

Guan, B., Waliser, D., and Ralph, F. M.: Water Vapor Budget in Atmospheric Rivers: A Multi-model Evaluation, Climate Prediction S\&T Digest, NOAA National Weather Service, Climate Prediction Center, Maryland, USA, p. 26, https://doi.org/10.25923/ae2c-v522, 2019.

Harris, S. M. and Carvalho, L. M.: Characteristics of southern California atmospheric rivers, Theor. Appl. Climatol., 132, 965-981, https://doi.org/10.1007/s00704-017-2138-1, 2018.

May, R., Arms, S., Marsh, P., Bruning, E., and Leeman, J.: MetPy: A Python Package for Meteorological Data, unidata, https://doi.org/10.5065/D6WW7G29, 2008-2017.

Nash, D.: GOES-17 ABI L2+ Cloud and Moisture Imagery Brightness Temperature: 4-6 March 2019, TIB, https://doi.org/10.5446/43737, 2019.

Nash, D.: Code for AR Thunderstorm - March 2019, Zenodo, https://doi.org/10.5281/zenodo.3885717, 2020.

Newell, R., Newell, N., Zhu, Y., and Scott, C.: Tropospheric rivers? A pilot study, Geophys. Res. Lett., 19, 2401-2404, https://doi.org/10.1029/92GL02916, 1992.

NOAA National Weather Service (NWS) Radar Operations Center: NOAA Next Generation Radar (NEXRAD) Level 3 Products Hail Signatures and One-Hour Precipitation, NOAA National Centers for Environmental Information, https://doi.org/10.7289/V5W9574V, 2019.

Oakley, N. S. and Redmond, K. T.: A climatology of 500-hPa closed lows in the northeastern Pacific Ocean, 1948-2011, J. Appl. Meteorol. Climatol., 53, 1578-1592, https://doi.org/10.1175/JAMCD-13-0223.1, 2014.
Oakley, N. S., Cannon, F., Munroe, R., Lancaster, J. T., Gomberg, D., and Ralph, F. M.: Brief communication: Meteorological and climatological conditions associated with the 9 January 2018 post-fire debris flows in Montecito and Carpinteria, California, USA, Nat. Hazards Earth Syst. Sci., 18, 3037-3043, https://doi.org/10.5194/nhess-18-3037-2018, 2018.

Pessi, A. T. and Businger, S.: Relationships among lightning, precipitation, and hydrometeor characteristics over the North Pacific Ocean, J. Appl. Meteorol. Climatol., 48, 833-848, https://doi.org/10.1175/2008JAMC1817.1, 2009.

Price, C. and Rind, D.: What determines the cloud-to-ground lightning fraction in thunderstorms?, Geophys. Res. Lett., 20, 463466, https://doi.org/10.1029/93GL00226, 1993.

Price, C. G.: Lightning applications in weather and climate research, Surv. Geophys., 34, 755-767, https://doi.org/10.1007/s10712012-9218-7, 2013.

Pruppacher, H. and Klett, J.: Microphysics of clouds and precipitation, Kluwer Acad., Norwell, MA, USA, 1997.

Ralph, F. M., Rutz, J. J., Cordeira, J. M., Dettinger, M., Anderson, M., Reynolds, D., Schick, L. J., and Smallcomb, C.: A scale to characterize the strength and impacts of atmospheric rivers, B. Am. Meteorol. Soc., 100, 269-289, https://doi.org/10.1175/BAMS-D-18-0023.1, 2019.

Ralph, M., Neiman, P., Wick, G., Gutman, S., Dettinger, M., Cayan, D., and White, A.: Flooding on California's Russian River: Role of atmospheric rivers, Geophys. Res. Lett., 33, L13801, https://doi.org/10.1029/2006GL026689, 2006.

Saha, S., Moorthi, S., Wu, X., Wang, J., Nadiga, S., Tripp, P., Behringer, D., Hou, Y.-T., Chuang, H.-Y., Iredell, M., Ek, M., Meng, J., Yang, R., Mendez, M. P., van den Dool, H., Zhang, Q., Wang, W., Chen, M., and Becker, E.: The NCEP climate forecast system version 2, J. Climate, 27, 2185-2208, https://doi.org/10.1175/JCLI-D-12-00823.1, 2014 (data available at: https://www.ncdc.noaa.gov/data-access/model-data/ model-datasets/climate-forecast-system-version2-cfsv2, last access: 19 November 2019).

USGS: Post-Fire Debris-Flow Hazards: Thomas Fire, available at: https://landslides.usgs.gov/hazards/postfire_debrisflow/ detail.php?objectid=178, last access: 3 September 2019.

Wallace, J. M. and Hobbs, P. V.: Atmospheric science: an introductory survey, vol. 92, Elsevier, New York, NY, USA, 2006.

Zhu, Y. and Newell, R. E.: Atmospheric rivers and bombs, Geophys. Res. Lett., 21, 1999-2002, 1994. 